\title{
PENGARUH VALUE CONGRUITY TERHADAP CUSTOMER BRAND IDENTIFICATION, BRAND ENGAGEMENT, DAN AFFECTIVE BRAND COMMITMENT SERTA DAMPAKNYA PADA BRAND LOYALTY MASYARAKAT DALAM MENGGUNAKAN TELPON GENGGAM IPHONE
}

\author{
Benjedid Ismet \\ Program Studi Magister Manajemen Universitas Tarumanagara \\ benjedid.ismed92@gmail.com \\ Eko Harry Susanto \\ Program Studi Magister Manajemen Universitas Tarumanagara
}

Masuk : 04-12-2020, revisi : 23-12-2020, diterima untuk diterbitkan : 28-12-2020

\begin{abstract}
This research was conducted to know the effect of value congruity on customer brand identification, brand engagement, and affective brand commitment and its impact on community brand loyalty in using iPhone cell phones. This research was conducted using the path analysis method using the partial least square approach. The research method used is quantitative research. The data collection method used is a questionnaire distributed to 96 people who have purchased products from the Apple brand and used Apple iPhone products at least 2 times. The results showed that value congruity has a significant positive effect on customer brand identification and brand engagement by the community in using iPhone cell phones. Value congruity has a significant positive effect on people's affective brand commitment in using iPhone mobile phones. Brand engagements do not affect community brand loyalty in using iPhone mobile phones, but customer brand identification has a significant positive effect on community brand loyalty in using iPhone mobile phones. And only brand engagement does not mediate the effect of value congruity on community brand loyalty in using iPhone mobile phones.
\end{abstract}

Keywords: Value Congruity, Customer Brand Identification, Brand Engagement, Affective Brand Commitment, Brand Loyalty

Abstrak: Penelitian ini dijalankan dengan tujuan untuk mengetahui pengaruh value congruity
terhadap customer brand identification, brand engagement dan affective brand commitment
serta dampaknya pada brand loyalty masyarakat dalam menggunakan telepon genggam
iPhone. Penelitian ini dijalankan dengan menggunakan metode analisis jalur menggunakan
pendekatan partial least square. Metode penelitian yang digunakan adalah penelitian
kuantitatif. Metode pengumpulan data yang digunakan adalah kuesioner yang disebarkan
kepada 96 orang yang pernah membeli produk dari brand Apple dan menggunakan produk
Apple iPhone setidaknya 2 kali. Hasil penelitian menunjukkan bahwa value congruity
berpengaruh positif signifikan terhadap customer brand identification dan brand engagement
masyarakat dalam menggunakan telepon genggam iPhone. Value congruity berpengaruh
positif signifikan terhadap affective brand commitment masyarakat dalam menggunakan
telepon genggam iPhone. Brand engagement tidak berpengaruh terhadap brand loyalty
masyarakat dalam menggunakan telepon genggam iPhone, namun customer brand
identification berpengaruh positif signifikan terhadap brand loyalty masyarakat dalam
menggunakan telepon genggam iPhone. Dan hanya brand engagement yang tidak memediasi
pengaruh value congruity terhadap brand loyalty masyarakat dalam menggunakan telepon
genggam iPhone.

Kata Kunci: Value Congruity, Customer Brand Identification, Brand Engagement, Affective Brand Commitment, Brand Loyalty 


\section{PENDAHULUAN}

\section{Latar Belakang}

Indonesia masuk dalam jajaran 10 besar konsumen online paling optimistis di dunia yaitu berada di peringkat keempat. Dapat disimpulkan bahwa memang Indonesia merupakan negara dengan gaya hidup yang suka berbelanja. Salah satu barang yang saat ini memang menjadi refleksi kekayaan seseorang adalah telepon genggam atau handphone. beberapa merek handphone yang memiliki produk yang sudah terkenal mahal seperti Apple dengan iPhone dan Samsung. Korea Selatan dengan Samsung-nya juga semakin memantapkan diri sebagai pemimpin smartphone global lalu disusul oleh beberapa brand dari China. Hal ini membuat iPhone semakin terhimpit karena mengalami penurunan penjualan. Hal ini menunjukkan bahwa secara global, iPhone memang sudah mulai kalah bersaing dengan perusahaanperusahaan telepon genggam lainnya. Hal inilah yang menjadi dasar penelitian ini dijalankan.

\section{Tujuan Penelitian}

Tujuan dari penelitian ini untuk mengetahui pengaruh value congruity terhadap brand loyalty, mengetahui pengaruh value congruity terhadap customer brand identification, mengetaui pengaruh value congruity terhadap brand engagement, mengetahui pengaruh value congruity terhadap affective brand commitment, mengetahui pengaruh customer brand identification terhadap brand loyalty, mengetahui pengaruh brand engagaement terhadap brand loyalty, mengetahui pengaruh affective brand commitment terhadap brand loyalty, mengetahui peranan customer brand identification dalam memediasi pengaruh value congruity terhadap brand loyalty, mengetahui peranan brand engagement dalam memediasi pengaruh value congruity terhadap brand loyalty, dan yang terakhir mengetahui peranan affective brand commitment dalam memediasi pengaruh value congruity terhadap brand loyalty masyarakat dalam menggunakan telepon genggam iPhone.

\section{TINJAUAN PUSTAKA}

\section{Value Congruity}

Value Congruity adalah tingkat kemiripan antara satu atau sekelompok pembeli dan konsumen di setiap pengambilan keputusan yang dapat diamati dalam beberapa karakteristik antara kedua belah pihak (merek dan konsumen) (Shirkhodaie \& Rastgoo-deylami, 2016).

\section{Brand Engagement}

Menurut Hollebeek et al. (2014), Brand Engagment atau keterlibatan merek sebagai motivasi pelanggan yang didorong oleh investasi atas sumber daya operan atau operan ke dalam interaksi merek, dan telah menjadi subjek peningkatan perhatian ilmiah pada dekade sebelumnya.

\section{Brand Identification}

Definisi dari identifikasi merek adalah dapat terjadi tanpa adanya interaksi langsung antara perusahaan dan konsumen melainkan hanya melalui produk dan persepsi yang ditanamkan oleh perusahaan dalam benak konsumen. Konsumen yang mempunyai Brand Identification yang kuat akan menjadi lebih loyal kepada merek tersebut untuk mendukung tujuan perusahaan, mempertahankan reputasi, mendukung produk perusahaan dan loyal (Bhattacharya \& Sen, 2003; He et al., 2012; Rather, 2018; So et al., 2017; Tuškej \& Podnar, 2018).

\section{Affective Brand Commitment}

Affective Brand Commitment adalah faktor emosional, yang berkembang melalui keterlibatan pribadi atau timbal balik yang dimiliki konsumen terhadap perusahaan, yang menghasilkan tingkat loyalitas dan komitmen yang lebih besar (Fullerton, 2003; Rather, 2018).

\section{Brand Loyalty}

Atilgan et al. (2005) telah menyatakan bahwa sesungguhnya sebuah merek atau brand yang kuat karena terciptanya brand association yang mengarah pada loyalitas merek yang lebih tinggi. 


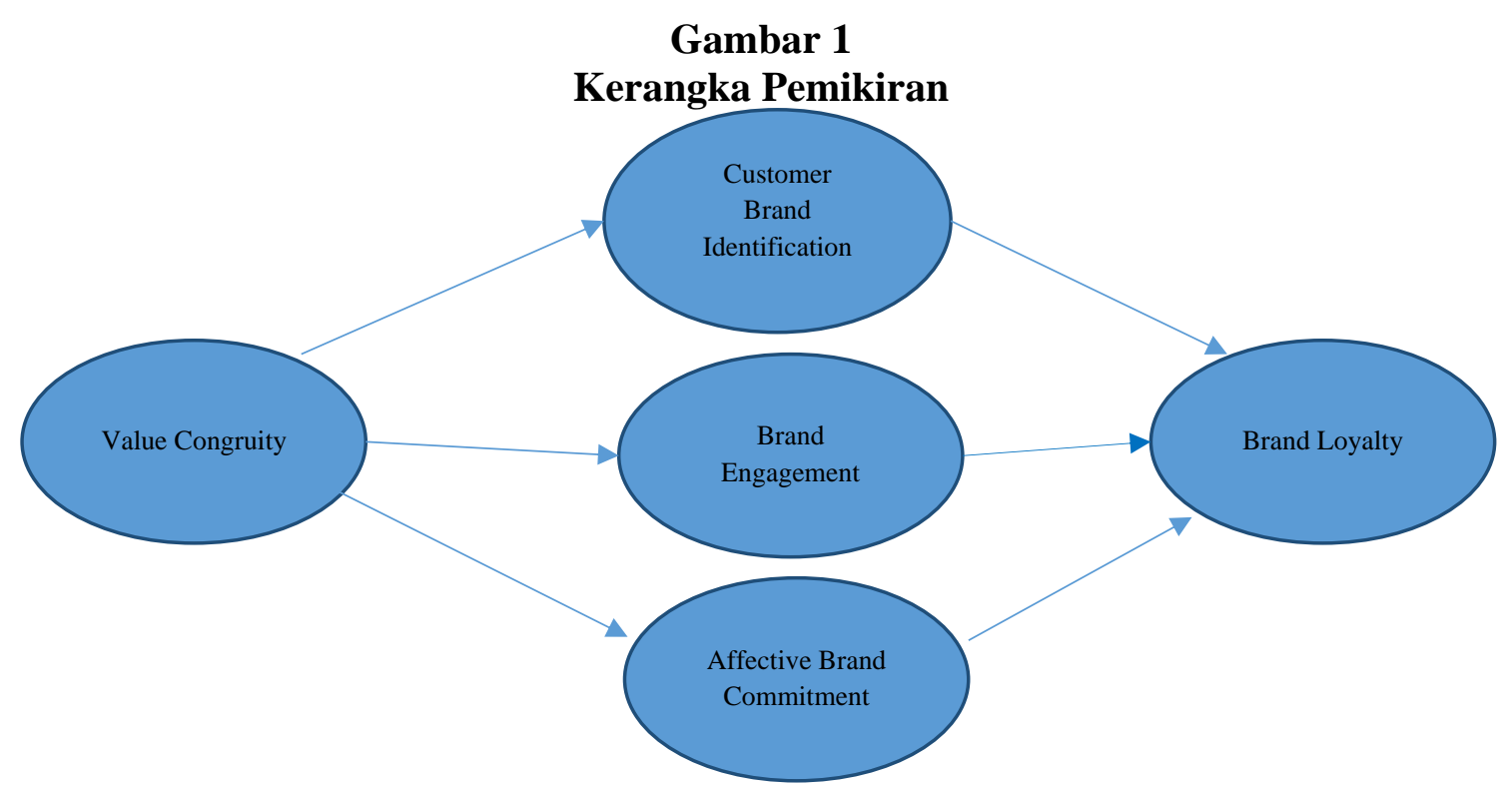

\section{Penelitian Terdahulu}

Penelitian yang dijalankan oleh Islam et al. (2018) serta Rather dan Camilleri (2019) dijelaskan bahwa seseorang dengan tingkat value congruity yang tinggi akan semakin terikat dengan sebuah brand karena adanya daya tarik yang positif dari brand tersebut. Hal ini menyebabkan brand tersebut secara tidak langsung akan membuat konsumen enggan untuk berpindah ke brand lain. Penelitian yang dijalankan oleh Larasati dan Hananto (2013) serta Rather (2018) dijelaskan bahwa value congruity memiliki pengaruh yang signifikan terhadap affective brand commitment. Hal ini terjadi karena saat seseorang telah merasakan adanya nilai yang sesuai dengan yang diharapkan, maka konsumen cenderung akan lebih berani untuk komitmen dengan brand tersebut. Konsumen yang merasakan value congruity memiliki pengalaman yang positif terhadap sebuah brand. Konsumen tersebut akan enggan untuk mencoba brand lain dan akan mencoba terikat dengan brand tersebut.

\section{METODOLOGI PENELITIAN}

Jenis penelitian yang digunakan dalam penelitian ini adalah penelitian kuantitatif dengan menggunakan pendekatan asosiatif. Menurut Sekaran dan Bougie (2013), metode penelitian kuantitatif dapat diartikan sebagai sebuah metode penelitian yang pemecahan masalahnya didasari atas perhitungan statistika dan matematika. Menurut Sarwono (2012), penelitian asosiatif adalah sebuah pendekatan dalam penelitian yang digunakan saat peneliti ingin meneliti keterkaitan sebab akibat antara 2 variabel atau lebih.

Sumber data yang dipakai dalam penelitian ini merupakan data primer. Menurut Sekaran dan Bougie (2013), data primer mengacu pada data yang diperoleh oleh peneliti dari tangan pertama yang berhubungan dengan variabel yang diteliti oleh peneliti untuk tujuan spesifik studi. Selanjutnya, skala yang digunakan pada penelitian ini adalah skala ordinal dimana menurut Supranto (2012), skala ordinal merupakan skala yang diwakilkan dengan sebuah angka yang selain berfungsi sebagai skala nominal yang merupakan lambang atau simbol untuk membedakan, skala ordinal juga berfungsi untuk mengetahui bahwa sesuatu lebih baik atau buruk daripada yang dibandingkan akan tetapi tidak sampai beberapa kali. Metode pengumpulan data yang digunakan pada penelitian ini adalah dengan berbentuk kuesioner. Menurut Sugiyono (2013), kuesioner merupakan teknik pengumpulan data yang dilakukan dengan cara memberikan seperangkat pertanyaan atau pernyataan tertulis kepada para responden untuk dijawab. Kriteria yang ditetapkan adalah responden pernah membeli produk Apple minimal 2 kali, responden telah menggunakan produk Apple iPhone setidaknya 2 kali.

Untuk mengetahui jumlah responden yang harus diambil, maka penelitian ini menggunakan metode perhitungan sampel menurut rumus Lemeshow. 
Keterangan:

$$
\mathrm{n}=\frac{z^{2} 1-\frac{\alpha}{2}(1-P)}{d^{2}}
$$

$\mathrm{n}=$ jumlah sampel

$\mathrm{z}=$ skor $\mathrm{z}$ pada kepercayaan $95 \%=1.96$

$\mathrm{p}=$ maksimal estimasi $=0.5$

Melalui rumus tersebut, ditemukan jumlah perhitungan sampel sebagai berikut:

$$
\mathrm{n}=\frac{1.96 .0 .5(1-0.5)}{0.1^{2}} \Rightarrow \mathrm{n}=\frac{3.8416 \times 0.25}{0.01} \Rightarrow \mathrm{n}=96.04=96 \text { responden }
$$

\section{Alat Analisis yang Digunakan}

Metode analisis pada penelitian ini menggunakan factor loading, uji cross loading, uji compositve reliability dan uji average variances extracted sebagai berikut :

1. Uji Factor Loading, dalam mengukur atau menilai validitas masing-masing variabel yang merupakan manifestasi dari indikator, maka dijelaskan jika faktor menunjukkan angka $>0,4$ maka indikator tersebut valid. Begitu juga sebaliknya jika faktor loading menunjukkan $<0,4$ maka dinyatakan tidak valid. Setiap manifestasi dari indikator yang tidak valid maka indikator tersebut dapat dinyatakan tidak memberikan dampak pada variabelnya dan perlu dihilangkan atau di drop (Singgih, 2012).

2. Uji Cross Loading digunakan untuk menunjukkan ketepatan indikator dalam mengukur konstruk eksogen dibandingkan dengan pengukuran terhadap konstruk eksogen lainnya.

3. Uji Composite Reliability ini menyatakan tingkat konsistensi pernyataan responden dalam melakukan pengisian kuesioner sebagai alat ukur dalam penelitian.

4. Uji Average Variance Extracted menunjukkan realibilitas kuesioner, yakni antara indikator dengan setiap konstruknya, baik konstruk eksogen maupun konstruk endogen. Nilai average variance extracted minimal yang disarankan untuk validitas sebuah kuesioner adalah > 0,5. Hal ini menunjukkan bahwa indikator reliable dalam menyusun konstruk eksogen (Ghozali, 2006).

\section{Hipotesis Statistik dan Pengujiannya}

Tahap selanjutnya setelah metode analisis maka peneliti akan melakukan pengujian terhadap hipotesis penelitian untuk mengetahui: 1) apakah variabel perceived quality (independen) memiliki pengaruh terhadap customer loyalty (dependen); 2) apakah variabel perceived quality (independen) memiliki pengaruh terhadap perceived risk (mediasi); 3) apakah variabel perceived quality memiliki pengaruh terhadap customer trust (mediasi); 4) apakah variabel perceived risk (mediasi) memiliki pengaruh terhadap customer loyalty (dependen); dan 5) apakah variabel customer trust (mediasi) memiliki pengaruh terhadap customer loyalty (dependen). Pengajuan hipotesis tersebut dilakukan dengan uji statistic dengan menggunakan Uji F dimana menurut Ghozali (2013) menjelaskan uji statistik F dilakukan untuk mengetahui apakah semua variabel independen yang dimasukkan dalam model mempunyai pengaruh secara bersama sama atau simultan kepada variabel dependen. Pengaruh variabel tersebut dilihat berdasarkan atas nilai signifikasi, jika nilai signifikasi $<0,05$ maka Ho ditolak, namun jika nilai signifikasi > 0,05 maka Ho diterima. Uji T menurut Ghozali (2013) menjelaskan bahwa uji parsial digunakan untuk mengetahui pengaruh dari masingmasing variabel independen terhadap variabel dependen. Uji $\mathrm{t}$ ini dilakukan dengan manggunakan probabilitas signifikan dengan tingkat singnifikasi sebesar 5\% $(\alpha=0.05)$. Menurut Ghozali (2013), dasar yang digunakan dalam uji t sebagai berikut: a) jika hasil dari pengujian lebih kecil dari 0.05 (sig < 0.05), maka Ho ditolak yang berarti variabel independen memiliki pengaruh signifikan pada variabel dependen; dan b) Jika hasil dari pengujian lebih besar dari 0.05 ( $\mathrm{sig}>0.05$ ), maka Ho diterima berarti variabel independen tidak memiliki pengaruh yang signifikan terhadap variabel dependen. 


\section{HASIL DAN KESIMPULAN}

\section{Pengujian Hipotesis}

Tabel 1

Hasil Uji Hipotesis

\begin{tabular}{|c|c|c|c|}
\hline & ORIGINAL SAMPLE & T STATISTICS & P VALUES \\
\hline VC -> BI & 0.814 & 18.161 & 0.000 \\
\hline VC -> CBE & 0.786 & 13.285 & 0.000 \\
\hline VC -> ABC & 0.763 & 13.095 & 0.000 \\
\hline BI -> CBL & 0.428 & 3.210 & 0.001 \\
\hline CBE -> CBL & 0.140 & 1.206 & 0.228 \\
\hline ABC -> CBL & 0.334 & 2.666 & 0.008 \\
\hline
\end{tabular}

Uji hipotesis pada penelitian ini dilakukan dengan melihat nilai t-statistics dan nilai $p$ values. Hipotesis penelitian dapat dinyatakan diterima apabila nilai nilai t-statistik lebih besar dari 1,96 dan nilai $p$-values $<0,05$.

Maka dari hasil penelitian yang dilakukan oleh peneliti dapat dijabarkan beberapa kesimpulan sebagai berikut:

1. Value congruity berpengaruh positif signifikan terhadap customer brand identification masyarakat dalam menggunakan telepon genggam iPhone.

2. Value congruity berpengaruh positif signifikan terhadap brand engagement masyarakat dalam menggunakan telepon genggam iPhone.

3. Value congruity berpengaruh positif signifikan terhadap affective brand commitment masyarakat dalam menggunakan telepon genggam iPhone.

4. Customer brand identification berpengaruh positif signifikan terhadap brand loyalty masyarakat dalam menggunakan telepon genggam iPhone.

5. Brand engageme tidak berpengaruh terhadap brand loyalty masyarakat dalam menggunakan telepon genggam iPhone.

6. Affective brand commitment berpengaruh positif signifikan terhadap brand loyalty masyarakat dalam menggunakan telepon genggam iPhone.

7. Customer brand identification memediasi pengaruh value congruity terhadap brand loyalty masyarakat dalam menggunakan telepon genggam iPhone.

8. Brand engagement tidak memediasi pengaruh value congruity terhadap brand loyalty masyarakat dalam menggunakan telepon genggam iPhone.

9. Affective brand commitment memediasi pengaruh value congruity terhadap brand loyalty masyarakat dalam menggunakan telepon genggam iPhone.

\section{DAFTAR PUSTAKA}

Atilgan, E., Aksoy, S., \& Akinci, S. (2005). Determinants of the brand equity: A verification approach in the beverage industry in Turkey. Marketing Intelligence \& Planning, 23(3), 237-248. https://doi.org/10.1108/02634500510597283

Bhattacharya, C. B., \& Sen, S. (2003). Consumer-company identification: A framework for understanding consumers' relationships with companies. Journal of Marketing, 67(2), 76-88. https://doi.org/10.1509/jmkg.67.2.76.18609

Fullerton, G. (2003). When does commitment lead to loyalty? Journal of Service Research, 5(4), 333-344. https://doi.org/10.1177/1094670503005004005

Ghozali, I. (2006). Aplikasi analisis multivariate dengan program SPSS (4th ed.). Badan Penerbit Universitas Diponegoro.

Ghozali, I. (2013). Aplikasi analisis multivariate dengan program IBM SPSS 21 update PLS regresi (8th ed.). Badan Penerbit Universitas Diponegoro.

He, H., Li, Y., \& Harris, L. (2012). Social identity perspective on brand loyalty. Journal of Business Research, 65(5), 648-657. https://doi.org/10.1016/j.jbusres.2011.03.007

Hollebeek, L. D., Glynn, M. S., \& Brodie, R. J. (2014). Consumer brand engagement in social media: Conceptualization, scale development and validation. Journal of Interactive Marketing, 28(2), 149-165. https://doi.org/10.1016/j.intmar.2013.12.002 
Islam, J. U., Rahman, Z., \& Hollebeek, L. D. (2018). Consumer engagement in online brand communities: A solicitation of congruity theory. Internet Research, 28(1), 23-45. https://doi.org/10.1108/IntR-09-2016-0279

Larasati, Y., \& Hananto, A. (2013). The role of value congruity and consumer brand identification toward development of brand commitment and positive word of mouth. SSRN Electronic Journal. https://doi.org/10.2139/ssrn.2200313

Rather, R. A. (2018). Investigating the impact of customer brand identification on hospitality brand loyalty: A social identity perspective. Journal of Hospitality Marketing and Management, 27(5), 487-513. https://doi.org/10.1080/19368623.2018.1404539

Rather, R. A., \& Camilleri, M. A. (2019). The customers' brand identification with luxury hotels: A social identity perspective. Harrison, T. \& Brennan, M. (Eds.) 2019 AMS World Marketing Congress, 429-443. https://doi.org/10.1007/978-3-030-42545-6_141

Sarwono, J. (2012). Metode riset skripsi pendekatan kuantitatif menggunakan prosedur SPSS (1st ed.). Elex Media Komputindo.

Sekaran, U., \& Bougie, R. (2013). Research methods for business: A skill building approach (5th ed.). John Wiley \& Sons.

Shirkhodaie, M., \& Rastgoo-deylami, M. (2016). Positive word of mouth marketing: Explaining the roles of value congruity and brand love. Journal of Competitiveness, 8(1), 19-37. https://doi.org/10.7441/joc.2016.01.02

Singgih, S. (2012). Statistik parametik. PT Gramedia Pustaka Utama.

So, K. K. F., King, C., Hudson, S., \& Meng, F. (2017). The missing link in building customer brand identification: The role of brand attractiveness. Tourism Management, 59, 640651. https://doi.org/10.1016/j.tourman.2016.09.013

Sugiyono. (2013). Metode penelitian kuantitatif, kualitatif dan $R \& D$. Alfabeta CV.

Supranto. (2012). Metode riset aplikasinya dalam pemasaran. PT Rineka Cipta.

Tuškej, U., \& Podnar, K. (2018). Consumers' identification with corporate brands: Brand prestige, anthropomorphism and engagement in social media. Journal of Product and Brand Management, 27(1), 3-17. https://doi.org/10.1108/JPBM-05-2016-1199 